\title{
Introduction. Urban Democracy: A South Asian Perspective
}

Stéphanie Tawa Lama-Rewal and Marie-Hélène Zérah

\section{CpenEdition}

\section{Journals}

\section{Electronic version}

URL: http://journals.openedition.org/samaj/3188

DOI: $10.4000 /$ samaj.3188

ISSN: $1960-6060$

\section{Publisher}

Association pour la recherche sur l'Asie du Sud (ARAS)

\section{Electronic reference}

Stéphanie Tawa Lama-Rewal and Marie-Hélène Zérah, « Introduction. Urban Democracy: A South Asian Perspective », South Asia Multidisciplinary Academic Journal [Online], 5 | 2011, Online since 30 December 2011, connection on 23 April 2019. URL : http://journals.openedition.org/samaj/3188 ; DOI : 10.4000/samaj.3188

This text was automatically generated on 23 April 2019

\section{$(1) \Theta \Theta$}

This work is licensed under a Creative Commons Attribution-NonCommercial-NoDerivatives 4.0 International License. 


\title{
Introduction. Urban Democracy: A South Asian Perspective
}

\author{
Stéphanie Tawa Lama-Rewal and Marie-Hélène Zérah
}

1 The 'urban question' has attracted increasing attention since the 1990s in the South Asian context because the issues at stake take on a particular urgency in the subcontinent for several reasons. A first, obvious reason is the increasing (and even strategic) importance of cities from a demographic, political and economic perspective. South Asia is home to 5 of the 10 largest cities-in fact, megacities-in the world. ${ }^{1}$ At the same time, with an urban population of 485 million, South Asia remains one of the least urbanized regions of the world ( $30 \%$ of its population live in cities). However, with an urban growth rate estimated at $2.7 \%$ per annum between 2000 and 2030, only second to Sub-Saharan Africa (Cohen, 2004), the urban population is bound to increase. Since $42.9 \%$ percent of this urban population lives in slums (with a proportion as high as $69 \%$ in Nepal and Bangladesh and 47\% in Pakistan) (Mathur 2010:11, quoting the figures of the State of the Asian Cities Report 2010/2011), the challenges of reducing existing and future poverty are increasingly played out in cities. Internationally, the adoption of new decentralization policies in the 1990s is part of the reform triptych 'decentralization-privatizationparticipation'. ${ }^{2}$ These reforms were seen as central to ensure that cities can function efficiently and fulfill their role as engines of economic growth. Thus the emergence of a new, international consensus on the major role of cities in the national and global economy translated into visions and policies focused on urban productivity and urban renewal. Indeed 'the erosion of traditional forms of sovereign political control by the nation state, the transnationalization of economic activity, and the shift to a service based economy have all increased the political centrality of the city, reversing the centuries long historical trends toward the increasing subordination of urban politics to national state apparatuses' (Tilly 2010, quoted in Heller \& Evans 2010: 434).

2 However in South Asia, the 'political centrality of cities' is far from being evident. On the one hand, the contrast between the weakness of cities, as a tier of government and vis-àvis regional and national political arenas, and their rising strength as a site of capital 
accumulation, does not conform to the political rise of cities and city-regions observed elsewhere (Scott 2001). This inability of local government to drive urban change is a serious concern, albeit for different reasons, for policy makers and academics alike.

On the other hand, South Asian cities are governed by a variety of urban regimes that are more or less democratic, sharing complex but unique historical legacies. Local democracy has had to function in the context of both democratic and non-democratic regimes-for instance under military rule in Pakistan, or under an authoritarian monarchy in Nepal.

Urban research on South Asia in the last 20 years has discussed, as we will see below, urban governance, urban movements and urban citizenship. Urban democracy is a much less used concept, and yet-as this issue hopes to demonstrate-it is a concept that provides the missing link between these various brands of research and offers a way out of their respective limitations. We argue that urban democracy is a key concept to think the relationship between urban mobilizations and urban change, or in other words, the relationship between urban politics and urban policies, in South Asia today.

\section{Multiple readings}

5 Urban democracy may look, at first, as a fuzzy concept. Indeed in the South Asian context, the idea of urban democracy immediately conjures up vivid images of a large variety of urban mobilizations-images that have largely circulated on TV, in newspapers and on the internet. One may think of demonstrations during the Jana Andolan (people's movements) in the streets of Kathmandu; or the political rallies of Benazir Bhutto in Lahore; or, more recently, of crowds gathering in the wake of Anna Hazare's anticorruption campaign in Delhi. Other images that come to mind are those of election times, when streets are festooned with strings of little flags bearing the colours of the competing parties, and crowded by the processions of candidates aspiring to become municipal councilors. Yet another vision is that of struggles around the city's resourcesbe it the Shiv Sena's attacks on North Indian migrants in Mumbai or the squatters' movement in Kathmandu, for example.

6 These various instances in fact suggest three distinct but related dimensions, or readings, of urban democracy, that correspond to three different spatial metaphors of the urban: (i) the urban as a bounded locale; (ii) the urban as a theatre; and (iii) the urban as a node in the state-society continuum. ${ }^{3}$

\section{Local democracy in the urban context}

7 This first definition of urban democracy considers the urban as a bounded locale. Since the 1990s, several South Asian states have adopted decentralization policies that redefine the status, responsibilities and resources of institutions of local self-government. These political reforms owe to the strong emphasis, by international funding institutions, on the expected benefits of decentralization in terms of efficiency and accountability; but they also meet objectives of domestic politics that may differ from one country to another -a point to which we will come back later. To take the case of India, through the $74^{\text {th }}$ Constitutional Amendment (1992), urban local bodies are given a constitutional status and new functions; municipal elections have to take place every five years under the supervision of State Election Commissions, and no more than 6 months can elapse 
between the end of a legislature and the beginning of the new one. Further, for metropolitan cities, ward committees are established in order to promote the participatory dimension of this new local-urban democracy. In Pakistan, the 2000 Devolution Plan redefines, too, the institutional architecture, functions, resources and accountability mechanisms of local assemblies. Moreover in both countries, but also in Nepal and in Bangladesh, substantial quotas for women are a strong, democratizing feature of decentralization policies (Ghosh \& Tawa Lama-Rewal 2005, Gellner \& Hachhethu 2008). On the whole, therefore, one could say that since the 1990s the political role of cities has been institutionally redefined and their responsibilities enlarged.

\section{Democracy as it is performed in cities}

8 This is a second definition of urban democracy-here the urban is seen as a theatre. Cities -especially large ones-are major sites of political, economic and cultural power: government offices, elected assemblies, courts, the main offices of large firms, television channels, newspaper offices, universities, all are usually located in cities. This concentration of power turns cities into a privileged theatre for different forms of demonstrative politics that are often-but not always-democratic. Cities are a foremost site for the performance of contentious politics-struggles whose object often goes much beyond the city itself. ${ }^{4}$ Because of their size and their inherent social diversity, urban crowds can-and do-act as a metaphor of the whole nation. The city, as a synecdoche for the country, then becomes not only a site, but also an actor of political struggles, as underlined by Ramaswamy's interview of Ranabir Samaddar in this issue. To go beyond the stage metaphor, one must also consider Nicholls' argument that 'the specific role of the city for general social movements is in its function as a relational incubator, ${ }^{5}$ facilitating complex relational exchanges that generate a diversity of useful resources for campaigns operating at a variety of spatial scales' (Nicholls 2008: 842).

\section{The city as an object of democratic struggles}

9 Many urban protests in the past decade have taken as their focus the city itself-that is, its resources in terms of space, employment, mobility, education, etc.- which points at a third possible understanding of urban democracy: the city as a central object of struggles over access to urban resources. In a world where urbanization is progressing at a fast pace, struggles for urban resources can be considered, as argued by Holston (2010), as drawing the new contours of citizenship. In other words, these struggles reshape the state-society relationship, which is what citizenship is about. If one considers citizenship as a boundary (Carrel et al. 2009: 17) between the included and the excluded, then the central role of the city is equally clear. While much of their appeal lies in their promise of inclusion, opportunities and social mobility-through employment, education, but also anonymity-large South Asian cities have been the site of many forms of exclusions. These are driven by a combination of market forces, elite-driven public policies and resistance to the changing social composition of cities. The contradictions between the lack of housing, the increasing number of slums and speculative real estate markets; the violence directed especially at poor migrants by 'sons of the soil' parties; and the brutal slum evictions in the name of urban renewal-all suggest that the boundary is fiercely guarded. 


\section{Fragmented literature}

10 with a vast and heterogeneous body of literature, ${ }^{6}$ out of which one can distinguish four groups of work that focus respectively on governance; (party) politics; social movements; and citizenship. This broad classification is meant to highlight a few significant perspectives and is by no means a rigid one-some texts fall in more than one category, and there are arguably overlaps between the categories themselves.

\section{Governance studies}

11 A large part of this body of research focuses on decentralization policies. An important section of the literature on decentralization has been largely normative, and can be roughly divided into two main types: (i) a programmatic literature, emanating from policy-makers and scholars, setting the new institutional framework of decentralization and the conditions for participatory practices; and (ii) a more speculative series of texts, emanating from the academia but also from international organizations, reflecting on the relationship between decentralization and the deepening of democracy (for instance Fung and Wright 2011, Blair 2000). The latter notion is a sub-theme in a literature which usually considers decentralization as a tool to make cities more efficient by reducing corruption and ensuring a better understanding of demand (Bardhan and Mukherjee 2006). The 'deep democracy' approach focuses on the potential benefits of (i) more inclusive representation at the local level (for instance through quotas); (ii) proximity between voters and elected representatives; and (iii) increased possibilities of participation-thus suggesting that the local could be the locus of regeneration of democracy.

In South Asia, the 2000s saw the development of a more empirical literature, investigating the implementation of decentralization policies. ${ }^{7}$ Studies of that kind reveal interesting similarities between India and Pakistan. In both cases this abundant literature underlines the discrepancy between the responsibilities delegated to local authorities and the human and financial means actually transferred to them (Cheema et al. 2005). The financial crunch of (urban) local bodies is indeed a central theme of the Indian literature on urban governance (see for instance Mathur 2006). Many studies also discuss the tensions between the cities' financial resources and their assigned role in the delivery of basic goods and services such as water, electricity, or housing (Sekhar \& Bidarkar 1999, Pethe \& Ghodke 2002). They scrutinize the extent and modalities of financial transfers to local bodies, and all of them agree that the gross inadequacy of such transfers, with reference to the tasks assigned to local bodies (at least on paper) is a major reason for the limitations of decentralization.

13 Another important check on decentralization is the limited role played by elected representatives at the municipal level. For India, this is highlighted by the malfunctioning ward committees (Baud \& de Wit 2009, Kennedy 2009) and in Pakistan, by the lack of accountability of local representatives (Cheema et al. 2005). From a longer term perspective, Ruet \& Tawa Lama-Rewal (2009) suggest that the marginalization of local politics observed in four Indian megacities actually manifest the containment of decentralization by political and administrative authorities at the state level-in

South Asia Multidisciplinary Academic Journal, 5 | 2011 
continuity with a phenomenon observed with regularity since the 1960s (Kumar 2006, Sivaramakrishnan 2000). The constant tension between decentralization and recentralization forces at work in the Jawaharlal Nehru National Urban Renewal Mission, launched in 2005 in India, ${ }^{8}$ is another example (Kennedy \& Zérah 2008, Sivaramakrishna 2011). This pendulum policy is also observed in Pakistan, where decentralization reforms have always been promoted by military regimes (under Ayub Khan in 1959-60, Zia-ul-Haq in 1979-80 and Pervez Musharraf in 2000-Cheema et al. 2005). These regimes, just like the 'Panchayat system' (1960-1990) established by the Shah dynasty in Nepal, made it a point to establish and maintain locally elected councils that they used as credentials of their democratic commitment. In other words, in these two countries local elections were meant to provide some legitimacy to non-democratic regimes that actually used them to further centralize their power.

Finally, decentralization reforms have failed to address the question of the space and scale of the urban; in other words, they have not adequately considered 'what and where is the urban' (Ward et al. 2011). In India, for instance, the metropolitan committees that were to be set up as per the $74^{\text {th }}$ Constitutional Amendment have either not been created or are in reality empty shells. As a consequence, the existing (and limited) political power of urban local bodies is exerted at the municipal jurisdictional level and does not encompass the functional limits of the urban agglomeration, exacerbating the disjunction between political and economic space (Zérah 2011, Sivaramakrishnan 2011).

Because decentralization was seen as part and parcel of other crucial reforms in the urban sector, it has been analyzed in terms of governance-a much contested concept internationally (Stoker 1998). Despite (or because of) its fuzzy nature, the notion of governance appeared uniquely able to capture the complexity (of processes, actors and institutions) that characterize the way big cities are governed today (Ruet \& Tawa LamaRewal 2009). This brand of research highlighted the strong dependence of urban local bodies from other levels of government, as well as their proximity with private actors such as the corporate sector. An international academic debate emerged around the unresolved location of democratic control in a context where elected governments seem to be marginalized among the various actors involved in decision-making processes (Hermet 2004, Jayal 2007). It appears today that this analytical framework led to overlooking, to some extent, the political dimension of decentralization and more largely participatory processes.

\section{Urban politics}

Politics and participation are precisely the focus of the second group of texts. Taking city politics as their focus, these works reveal a contrast between India and Pakistan. Ahmad's paper (this issue) refers to the large literature on Karachi politics, and particularly on the role of the Muhajir Qaumi Movement (MQM) in that city. But as far as India is concerned, few texts address the urban dimension of local politics, or the local dimension of urban politics, and many of them were written by American scholars in the 1970s (Oldenburg 1976, Rosenthal 1976, Weiner 1976). A prominent exception here is the literature on the Shiv Sena, a regional party built on the promotion of the 'sons of the soil' in Bombay. The party has a dense network of local branches in the capital city of Maharashtra, on which it has been able to rely and which allows him to be a major player in both municipal and state elections (Kaviraj \& Katzenstein 1981, Gupta 1982, Hansen 2001). ${ }^{9}$ This situation 
however might change in the near future: as more and more constituencies will fall in the urban category, one can expect stronger linkages between politics at the city and at the higher (state or national) level, and consequently increased scholarly interest can be expected. Recent work on Ahmedabad politics (Berenschott 2010, Rajagopal this issue, Chatterjee 2009, 2011), aiming at uncovering the relationships between city politics and economic restructuring, are one example. The importance of understanding city politics is underlined by Ray (1998: 23) in her work on women's movements in Bombay and Kolkata. She argues that the positioning, ideologies and strategies chosen by social movements are embedded with the arena of formal politics. Because of this embeddedness, she prefers the notion of 'protest field' to that of social movement. ${ }^{10}$

\section{Urban social movements}

As far as India is concerned, identifying these works can prove difficult, because only a small part of the literature on social movements explicitly focuses on the urban (Shah 2002). Within this limited literature, the issue of class is prominent. But in today's India, 'informality [which concerns more than $90 \%$ of the workforce] poses serious challenges both to the theorists and practitioners of class politics' (Roychowdhury 2008: 604). Collective action by workers in the informal sector is being documented (Sheth 2004, Dasgupta 2009), but there is usually no discussion of the links between these mobilizations and local democracy. An exception is Omvedt's account of the Dalit movement, describing how the short-lived Dalit Panthers' movement, 'born in the slums of Bombay' in 1972, engaged with electoral politics as it opposed both the Congress and the Shiv Sena (Omvedt 2002).

However if we include in this category works that focus on a particular urban-based organization or coalition of organizations, then the relevant literature is much larger. This loose definition of 'social movements' (or 'protest fields', to follow Ray's terminology) seems justified by the important insights on urban democracy offered by such works. If housing is, as Castells (1983) argued, replacing work as the central issue of social movements, then urban protests constitute a privileged prism to observe the practices of democratic expression in South Asian megacities today. Indeed what Appadurai writes about Bombay-'[...] housing can be argued to be the single most critical site of [the] city's politics of citizenship' (Appadurai 2001: 27) - holds true for all South Asian megacities. ${ }^{11}$

19 For Appadurai, the notion of 'deep democracy' can materialize when the poor act strategically and take participatory practices in their own hands (Appadurai, 2001: 37). A classic example is his defense and illustration of this notion through the case study of the Mumbai 'Alliance', a coalition of three organizations that has been working towards protection and visibility of the poor in that city. A similar example of such large-based coalitions is the internationally acknowledged Orangi Project in the slums of Karachi. The 'Alliance' and the Orangi project take the city and its resources as an object of their struggles. These urban movements clearly aim at changing the power geometry and 'reshape' local democracy (Mitlin, 2004) by asserting their rights and their presence in the city, even though their actual modes of action on the ground can contradict these objectives. ${ }^{12}$ 


\section{Citizenship studies}

20 These texts actually can be seen as providing a bridge between the three strands of literature described above. Since they often have an empirical focus on various actors ( neighbourhood associations, private utilities, real estate interests), they provide insights in shifts on urban governance, yet they are characterized by a major concern about the relationship between class and political participation (in the most extensive sense)-see Jha et al. 2007, Weinstein 2009. While empirically focusing on a variety of urban policies or projects, they build a collective argument around the centrality of class dynamics in the current transformations of urban democracy: the changing repertoire of collective action, the new role of courts, the ascendancy of discourses that conflate illegality and illegitimacy-all of which contribute to the commonly observed relegation of the poor to urban peripheries. These works are fundamentally concerned with citizenship insofar as they critically analyze the discourses and practices that enable and legitimize the increasing appropriation of urban resources by a minority of urban population, namely the urban rich-often called the 'middle class'. ${ }^{13}$ Thus Ghertner, analyzing court cases related to slum evictions in Delhi, highlights the potency of 'discursive devices' in constructing a 'property-based citizenship' (Ghertner 2008: 66). 'Are Indian cities becoming bourgeois at last?' Partha Chatterjee asks in a much discussed essay (Chatterjee 2004) in which he describes political participation in Indian cities in binary terms. He contrasts the 'political society', structured by parties, dealing with 'populations' whose relationship with the state consists of favours, with 'civil society' made up of 'proper citizens' who mobilize through associations and who know their rights. The term 'bourgeois', which explicitly evokes the combination of economic and political clout enjoyed by the urban rich, is also used by Baviskar in her analysis of 'bourgeois environmentalism' in Delhi (Baviskar 2011). Like Chatterjee, Harriss (2007: 2717) sees political participation in Indian cities as structured along a binary pattern: for him the 'old politics' rooted in political parties and trade unions is being increasingly marginalized by the 'new politics' emerging around community-based civil society organizations and new social movements. While these two authors have stimulated research on the role of class in structuring political participation in Indian cities, a series of recent empirical studies have highlighted the limits of these binary models and underlined significant overlaps (Coelho \& Venkat 2009).

\section{Urban democracy and the materiality of urban space}

21 These four strands of literature offer a wealth of empirical evidence on various kinds of urban mobilizations, often in relationship to specific urban projects. Together, this series of works suggest important insights on the relationship between urban restructuring or renewal and urban mobilizations-a relationship that is of crucial importance to understand the nature and the stakes of urban democracy. To be more precise, the literature suggests that the relationship between urban restructuring and urban mobilization is a complex, ambivalent one, insofar as it can take three different directions. 


\section{Three types of relationship}

22 A first type of relationship is when urban planning stimulates new mobilizations that ultimately influence the restructuring of urban space. One major example here is the contestation over land use that shook Delhi in 2006. To grossly summarize, the courts and the neighborhood associations of well off areas supported the new Master Plan based on zoning, while other neighbourhood associations, political parties and traders supported the status quo, i.e. mixed land use. Mehra's (2009) analysis of this conflict shows that, among the various modes of mobilizations provoked by the conflict (from press campaigns to Public Interest Litigations to sit-ins and demonstrations), the more classic ones proved their enduring efficiency, since the traders' camp, that resorted to demonstrations and sit-ins, finally managed to get the new Master plan amended so as to enforce mixed land use. Another example is the study by Gill (2006) on the political mobilization of deprived castes in Delhi with regard to legislation (passed in 1999-2000) that threatened the informal recycling sector. This work, underlining the enduring importance of caste identification to gain access to urban resources, is exceptional insofar as most research on urban citizenship focuses on class and overlooks caste (see also Mehra 2011).

23 A second type of relationship is when mobilizations do support urban restructuring and the marginalization of the poor. A number of such mobilizations have been shown to be triggered by neighbourhood associations (Ghertner 2008) or environmental NGOs (Zérah 2007, Véron 2006). ${ }^{14}$ They have converged with judicial activism, which has played a crucial role in a series of court cases that have led to the demolition and eviction of slums, consequently reshaping urban space and access to urban livelihoods.

However other types of mobilizations, led by different social groups, may oppose, support, or, in a more ambivalent way, disturb initiatives that pertain to urban restructuring. These are more amorphous and can consist of unexpected coalitions against a project or a reform. For instance the construction of a large sea-link bridge in Mumbai was opposed by fishermen, resident welfare associations and environmental groups who had different interests and different modes of mobilizations but did constitute an unforeseen interest group (Zérah 2011). In Mumbai again, Bawa (2009) finely analyzed the coalition of community-based organizations, NGOs and churches against an attempt to privatize water supply in one area of the city, and the informal role played by engineers (officially supporting the project but providing-under coverinformation that proved impossible to gather through the use of the Right to Information). ${ }^{15}$

\section{Insurgent cities?}

Notwithstanding their different natures, these three types of relationship all underline the importance of contestations, resistance and dissent in the changing materiality of South Asian cities. This central feature of South Asian urban politics is a compelling one and is being increasingly theorized. Both Roy (2009) and Benjamin (2008) explore the circulation flows between the formal and informal segments of urban politics and economy. They analyze the informal 'idiom of urbanization' (Roy 2009) that characterize strategies of the poor ('occupancy urbanism' (Benjamin 2008) being a case in point), but 
also of the rich, and the planning exercise itself: '[...] urban planning in India has to be understood as the management of resources, particularly land, through dynamic processes of informality. By informality I mean a state of deregulation, one where the ownership, use and purpose of land cannot be fixed and mapped according to any prescribed set of regulations or the law' (Roy 2009: 80). Research on Pakistan (see Ahmad's literature review in this issue) also shows that everyday politics is most often played in informal ways, on the margins of formal representative democracy.

The issue of urban citizenship is central in these works. They point to a form of 'insurgent citizenship' (Holston 2010: 2) that aims at countering the unequal application of rules and law to all (in other words the disjunction between the formal rules of democracy and its substance). However, despite multifarious ways of claiming a 'right to the city' (Lefebvre 1968) - that can also be understood as 'the right to have rights' (Holston 2010)-is 'insurgent citizenship' actually observed in the South Asian case? This question is tackled upfront in a recent collection of papers on the 'right to the city in India' (Zérah et al. 2011). This volume highlights the many ways in which urban citizenship is 'conditional' in India (Zérah et al. 2011: 11) despite various strategies to make claims on urban resources or to resist urban restructuring. It underscores the limits to the "political transformation that occurs when the conviction of having a right to the city turns residents into active citizens who mobilize their demands through residentially-based organizations that confront entrenched national regimes of citizen inequality' (Holston 2010: 2).

Works on the informal thus appears to suffer from a flaw that is symmetrical to the limitations of many governance studies: while the former's exclusive focus on micro-level arrangements ignores the momentum imposed by urban reforms, the latter's excessive attention to institutional constructions misses the complex processes through which reforms are resisted, derailed, or simply interpreted. The concept of urban democracy, precisely because it is multi-dimensional, suggests the possibility to consider how institutional architecture and collective action, formal and informal urban politics, function together.

\section{Five papers on four cities}

This special issue considers together (i) the role of democracy (or lack of it) in the city (Ramaswamy, Heuzé, Ahmad); (ii) the redeployment of urban politics along with economic restructuring (Rajagopal); and (iii) the role of the city in democracy (Gazdar \& Mallah) - which suggests that the three dimensions of urban democracy are not mutually exclusive but on the contrary overlap and reinforce each other. The five papers in this issue focus on four South Asian cities-Karachi, Kolkata, Mumbai and Ahmedabad-while the book review adds elements about Delhi. These papers contribute to afore mentioned debates and bring original perspectives on urban democracy, on three major points.

Firstly, both Heuzé's paper on Mumbai and Samaddar's interview on Kolkata offer a much needed dynamic view of the shapes, actors and objects of urban democracy over the past 40 years, which suggests that urban protests are increasingly linked to the materiality of the city. These texts show that as the city changes, the types, nature and sites of protests also change. The interview of R. Samaddar by Ramaswamy shows the evolution of the arenas in which intellectuals sought to engage with the political realm, from radical politics to NGOs and think tanks. The aspiration and the rise of the urban middle classes 
as well as a process of deindustrialization and economic restructuring have reshaped the interactions between economy, politics and forms of protest. As Samaddar puts it: 'the old style of protest is not possible'-an observation echoed in Heuzé's paper, showing how the decline of the working class in Mumbai and the tertiarization of the economy have transformed the manner in which the city is governed.

Yet all five papers show the resilience of a traditional repertoire of collective action along with the emergence of new forms of mobilization; thus these papers contribute to questioning the theorization of urban political participation in binary terms, since they all suggest serious overlaps between 'civil' and 'political' society (Chatterjee 2004), as well as between 'old' and 'new' politics (Harriss 2007). In particular, these papers show that the role of political parties and political leadership remain crucial in defining a city's political culture, be it the Shiv Sena in- the 'tej city' of Mumbai (Heuzé), the Communist Party of India-Marxist (CPI-M) in the 'anarchic city' of Kolkata (Samaddar), the MQM in Karachi or the BJP in Ahmedabad. This implies that urban studies have to pay more attention to these major, but often overlooked, actors ${ }^{16}$ of urban democracy.

Secondly, all papers in this issue engage with the importance of violence in urban politics. Rajagopal's essay relates urban restructuring in Ahmedabad with the exercise of political violence that gives birth to 'special political zones', that is, zones of exceptionality vis-àvis political rights. Violence, in this case, is part of a political project, partly disguised as reshaping the city. Gazdar \& Mallah and Ahmad look at violence from a more localized point of view, but both their papers bring out the central role of 'turf wars' in Karachi. Ahmad's paper in fact opens a new perspective on the issue of urban political violence by finely looking at the importance of everyday practices. As she considers the strategies and tactics of Karachi inhabitants to avoid the violence associated with parties' turf, Ahmad studies by-standing as a less visible form of protest, that is in itself a mode of political participation, thereby suggesting a new, radical meaning to the old notion of 'passive citizenship'. By-standing, she argues, is one of the many ways of reclaiming spaces, especially public spaces. This perspective presents some similarity with the survival strategies of slum dwellers who construct shared interests with a view to get urban settlements regularized (Gazdar \& Mallah).

Thirdly, the notion of claim-if not right-to the city is at the core of papers by Gazdar and Mallah and by Rajagopal, suggesting that urban democracy is a twin concept of urban citizenship. Gazdar and Mallah, analyzing the politics of unauthorized colonies in Karachi (which is strikingly similar to that observed in Indian cities), show how the regularization of unauthorized settlements manifests a democratization-in the sense of an opening of access to hitherto excluded social groups-of urban democracy. Rajagopal highlights the 'socio-spatial dialectic' (Soja 1980) that redefines urban citizenship for Muslims in Ahmedabad: what he calls 'Special Political Zones' is precisely the denial of the right to the city.

Finally, all these papers provide a window into the uniqueness of the cities studied and contribute to questioning the single, global model of the 'neo-liberal' city and to demonstrating the importance of local contextualization in urban theory. Calling for a renewed, comparative and cosmopolitan urbanism, Robinson (2006) urges us to understand 'ordinary cities' in their uniqueness rather than as fitting (or not) theoretical models provided by research on cities located in the North. In South Asia as elsewhere, much of urban research in the 1990s and 2000s has tended to read urban transformations as a coherent project of neo-liberalizing the urban (for instance, on Mumbai, see Nijman 
2008, Banerjee-Guha 2009, Whitehead \& More 2007). Today an increasing part of South Asian urban research is grounded in an 'epistemology of the particulars' (Castree 2005) that aims at unpacking the embeddedness of global and local processes. As pointed out by Anjaria and Mc Farlane (2011) this is a rich and productive route to characterize South Asian cities. Urban diversity, the place of urban informality, along with constantly negotiated political processes (Roy 2009, 2011) and local agency (Shatkin 2007) need to be at the core of understanding these ordinary cities. We hope that this special issue will be a useful contribution to this debate, by enriching empirically and theoretically the understanding of the many dimensions of urban democracy. In the end, we hope to demonstrate that though 'ordinary', South Asian cities are far from being so.

\section{BIBLIOGRAPHY}

Anjaria, Jonathan S.; McFarlane, Colin (2011) Urban Navigations: Politics, Space and the City in South Asia, Delhi: Routledge.

Appadurai, Arjun (2001) 'Deep Democracy: Urban Governmentality and the Horizon of Politics', Environment and Urbanization, 13(2), pp. 23-43.

Banerjee-Guha, Swapna (2009) 'Neoliberalising the 'Urban': New Geographies of Power and Injustice in Indian Cities', Economic and Political Weekly, 44(22), pp. 95-107.

Bardhan, Pranab; Mookherjee, Dilip (2006) 'Decentralisation and Accountability in Infrastructure Delivery in Developing Countries', The Economic Journal, 116(508), pp. 101-127.

Baud, Isa; Nainan, Navtej (2008) “Negotiated Spaces’ for Representation in Mumbai: Ward Committees, Advanced Locality Management and the Politics of Middle-Class Activism', Environment and Urbanization, 20(2), pp. 483-99.

Baud, Isa; De Wit, Joop (2009) New Forms of Urban Governance in India: Shifts, Models, Networks and Contestations, Delhi: Sage.

Baviskar, Amita (2011) 'Cows, Cars and Rickshaws: Bourgeois Environmentalist and the Battle for Delhi's Streets', in Amita Baviskar \& Raka Ray (eds.), Elite and Everyman: The Cultural Politics of the Indian Middle-classes, New Delhi: Routledge.

Bawa, Zainab (2009) 'K-East WDIP Case Study' paper presented in the conference on The Voice of City Dwellers in Urban Governance. Participation, Mobilisation, and Local Democracy-Comparing Indian/ South African Debates, Mumbai University, 12-14/01/2009.

Benjamin, Solomon (2008) 'Occupancy Urbanism: Radicalizing Politics and Economy beyond Policy and Programs', International Journal of Urban and Regional Research, 32(3), pp. 719-29.

Berenschot, Ward (2010) 'Everyday Mediation: The Politics of Public Service Delivery in Gujarat, India', Development and Change, 41(5), pp.883-905.

Blair, Harry (2000) 'Participation and Accountability at the Periphery: Democratic Local Governance in Six Countries', World Development, 28(1), pp. 21-39. 
Carrel, Marion; Neveu, Catherine; Ion, Jacques (eds.) (2009) Les intermittences de la démocratie. Formes d'action et visibilités citoyennes dans la ville, Paris: L'Harmattan.

Castells, Manuel (1983) The City and the Grassroots: A Cross-Cultural Theory of Urban Social Movements, Berkeley: University of California Press.

Castree, Noël (2005) ‘The Epistemology of Particulars: Human Geography, Case Studies and “Context”, Geoforum, 36(5), pp. 541-44.

Chakrabarti, Poulomi (2008) 'Inclusion or Exclusion? Emerging Effects of Middle-Class Citizen Participation on Delhi's Urban Poor', IDS Bulletin, 38, pp. 96-104.

Chatterjee, Ipsita (2009) 'Social Conflict and the Neoliberal City: a Case of Hindu-Muslim Violence in India', Transactions of the Institute of British Geographers, 34(2), pp. 143-160.

Chatterjee, Ipsita (2011) ‘Governance as Performed, Governance as Inscribed: New Urban Politics in Ahmedabad', Urban Studies, 48(12), pp. 2571-90.

Chatterjee, Partha (2004) The Politics of the Governed. Reflections on Popular Politics in Most of the World, Columbia: University Press.

Cheema, Ali; Khwaja, Asim I.; Qadir, Adnan (2005) 'Decentralization in Pakistan: Context, Content and Causes', Harvard University: Faculty Research Working Papers Series, RWP05-034.

Coelho, Karen; Venkat, T. (2009) 'The Politics of Civil Society: Neighbourhood Associationism in Chennai', Economic and Political Weekly, 44 (26-27), pp. 358-67.

Cohen, Barney (2004) ‘Urban Growth in Developing Countries: A Review of Current Trends and a Caution Regarding Existing Forecasts', World Development, 32(1), pp. 23-51.

Dasgupta, Keya (2009) 'The Hawkers' Movement in Kolkata: Negotiating the Right to City Space', paper presented in the conference on The Voice of City Dwellers in Urban Governance. Participation, Mobilisation, and Local Democracy-Comparing Indian/South African debates, Mumbai University, $12-14 / 01 / 2009$.

Dembowski, Hans (1999) 'Courts, Civil Society and Public Sphere: Environmental Litigation in Calcutta', Economic and Political Weekly, 34 (1-2), pp. 49-56.

Dupont, Véronique; Ramanathan, Usha (2009) 'The Courts and the Squatter Settlements in Delhi -Or the Intervention of the Judiciary in Urban Governance', in Isa Baud \& Joop De Wit (eds.), New Forms of Urban Governance in India: Models, Networks, and Contestations, Delhi: Sage, pp. 312-43.

Fernandes, Leela (2007) India's New Middle Class: Democratic Politics in an Era of Economic Reform, New Delhi: Oxford University Press.

Fung, Archon; Wright, Erik Olin (2001) 'Deepening Democracy: Innovations in Empowered Participatory Governance', Politics \& Society, 29(1), pp. 5-41.

Gellner, David N.; Hachhethu, Krishna (2008) Local Democracy in South Asia: Microprocesses of Democratization in Nepal and its Neighbours, Delhi: Sage.

Ghertner, D. Asher (2008) 'Analysis of New Legal Discourse behind Delhi's Slum Demolitions', Economic and Political Weekly, 43(20), pp. 57-66.

Ghertner, D. Asher (2011) Gentrifying the State, Gentrifying Participation: Elite Governance Programs in Delhi, International Journal of Urban and Regional Research, 35, pp. 504-32.

Ghosh, Archana; Tawa Lama-Rewal, Stéphanie (2005) Democratization in Progress. Women and Local Politics in Urban India, New Delhi: Tulika Books. 
Gill, Kaveri (2006) ‘Deprived Castes and Privileged Politics: An Urban Informal Market in Contemporary India', Economic and Political Weekly, 41(2), pp. 133-41.

Haider, Murtaza; Badami, Madhav G. (2010) 'Urbanization and Local Governance Challenges in Pakistan', Environment and Urbanization Asia, 1 (1), pp. 81-96.

Hansen, Thomas Blom (2001) Violence in Urban India: Identity Politics, 'Mumbai', and the Postcolonial City, Delhi: Permanent Black.

Harriss, John (2007) 'Antinomies of Empowerment: Observations on Civil Society, Politics and Urban Governance in India', Economic and Political Weekly, 42(26), pp. 2716-24.

Heller, Patrick; Evans, Peter (2010) 'Taking Tilly South: Durable Inequalities, Democratic Contestation, and Citizenship in the Southern Metropolis', Theory and Society, 39, pp. 433-50.

Hermet, Guy (2004) 'Un régime à pluralisme limité? A propos de la gouvernance démocratique', Revue Française de Science Politique, 54(1), pp. 159-78.

Holston, James (2010) 'Right to the City, Right to Rights and Urban Citizenship', paper presented in the conference on The $21^{\text {st }}$ Century Indian City: Developing an Agenda for Urbanization in India, Delhi, India International Centre, March 23-25.

Jayal, Niraja Gopal (2007) ‘Review Essay: On Governance’, Current Sociology, 55(1), pp. 126-35.

Jha, Saumitra; Rao, Vijayendra; Woolcock, Michael (2007) ‘Governance in the Gullies: Democratic Responsiveness and Leadership in Delhi's Slums', World Development, 35(2), pp. 230-46.

Katzenstein, Mary F. (1979) Equality and Ethnicity-Shiv Sena Party and Preferential Policies in Bombay, Ithaca: Cornell University Press.

Kennedy, Loraine (2009) 'New Patterns of Participation Shaping Urban Governance', in Joel Ruet \& Stéphanie Tawa Lama-Rewal (eds.), Governing India's Metropolises: Case Studies of Four Cities, Delhi: Routledge, pp. 55-80.

Kennedy, Loraine; Zérah, Marie-Hélène (2008) 'The Shift to City-Centric Growth Strategies in India, Perspectives from Hyderabad and Mumbai', Economic and Political Weekly, 43(39), pp. 110-17. Kumar, Girish (2006) Local Democracy in India: Interpreting Decentralization, Sage: New Delhi. Lefebvre, Henri (2009) Le droit à la ville, Paris: Economica-Anthropos, [1968].

Mathur, Om Prakash (2006) 'Urban Finance’, in 3i Network, India Infrastructure Report 2006, New Delhi: Oxford University Press, pp. 82-105.

Mathur, Om Prakash (2010) 'Urban Challenges in South and South-West Asia', paper presented in the Fifth Asia-Pacific Urban Forum 2011 organized by United Nations-ESCAP, 21 p.

Mehra, Diya (2009) 'Campaigning against its Eviction: Local Trade and 'World Class' Delhi', in Melissa Butcher \& Selvaraj Velagotham (eds.), Dissent and Cultural Resistance in Asian Cities, Routledge: London.

Mehra, Diya (2011) 'Caste and Class in Indian Cities: Habitation, Inequality and Segregation', in Marie-Hélène Zérah, Véronique Dupont, Stéphanie Tawa Lama-Rewal (eds.) Urban Policies and the Right to the City in India: Rights, Responsibilities and Citizenship, UNESCO, Delhi, 2011, pp. 39-42 ( http://unesdoc.unesco.org/images/0021/002146/214602E.pdf).

Miraftab, Faranak (2004) 'Invited and Invented Spaces of Participation: Neoliberal Citizenship and Feminists' Expanded Notion of Politics', Wagadu, 1, pp. 1-7.

Mitlin, Diana (2004) ‘Reshaping Local Democracy’, Environment and Urbanization, 16(1), pp. 3-8. 
Nicholls, Walter J. (2008) 'The Urban Question Revisited: The Importance of Cities for Social Movements', International Journal of Urban and Regional Research, pp. 841-59.

Nijman, Jan (2008) 'Against the Odds: Slum Rehabilitation in Neoliberal Mumbai', Cities, 25(2), pp. 73-85.

Oldenburg, Philippe (1976) Big City Government in India: Councilor, Administrator and Citizen in Delhi, Delhi: Manohar.

Omvedt, Gail (2002) 'Ambedkar and After: The Dalit Movement in India', in Ghanshyam Shah (ed.), Social Movements and the State, Delhi: Sage, pp. 292-309.

Pethe, Abhay; Ghodke, Manju (2002) 'Funding Urban Infrastructure: From Government to Markets', Economic and Political Weekly, 37(25), pp. 2467-70.

Ray, Raka (1998) ‘Women's Movements and Political Fields: A Comparison of Two Indian Cities', Social Problems, 45(1), pp. 21-36.

Robinson, Jennifer (2006) Ordinary Cities: between Modernity and Development, London/New York: Routledge.

Rosenthal, Donald B. (ed.) (1976) The City in Indian Politics, Faridabad: Thomson Press (India) Limited.

Roy, Ananya (2009) 'Why India Cannot Plan Its Cities: Informality, Insurgence and the Idiom of Urbanization', Planning Theory, 8(1), pp. 76-87.

Roy, Ananya (2011) ‘Slumdog Cities: Rethinking Subaltern Urbanism', International Journal of Urban and Regional Research, 35(2), pp. 223-38.

Roychowdhury, Supriya (2008) ‘Slums and Civil Society: The Limits of Urban Activism', in Darshini Mahadevia (ed.), Inside the Transforming Urban Asia. Processes, Policies and Public Actions, Delhi: Concept, pp. 601-18.

Ruet, Joel; Tawa Lama-Rewal, Stéphanie (eds.) (2009) Governing India's Metropolises, Delhi: Routledge.

Scott, Allen John (ed.) (2001) Global City-Regions: Trends, Policy, Theory, Oxford: Oxford University Press.

Shah, Ganshyam (ed.) (2002) Social Movements and the State, Delhi: Sage.

Sharma, R.N.; Bhide, Amita (2005) 'World Bank Funded Slum Sanitation Programme in Mumbai: Participatory Approach and Lessons Learnt', Economic and Political Weekly, 40(17), pp. 1784-89.

Shatkin, Gavin (2007) 'Global Cities of the South: Emerging Perspectives on Growth and Inequality’, Cities, 24(1), pp. 1-15.

Sekhar, Sita; Bidarkar, Smita (1999) 'Municipal Budgets in India', Economic and Political Weekly, 34 (20), pp. 1202-08.

Sheth, D.L., (2004) 'Globalisation and New Politics of Micro-Movements', Economic and Political Weekly, 39(1), pp. 45-58.

Sivaramakrishnan, K. C. (2000) Power to the People? The Politics and Progress of Decentralisation, Delhi: Konark Publishers.

Sivaramakrishnan, K. C. (2011) Re-Visioning Indian Cities: The Urban Renewal Mission, New Delhi: Sage. 
Stoker, Gerry (1998) ‘Governance as Theory: Five Propositions’, International Social Sciences Journal, 55, pp. 17-28.

Soja, Edward W. (1980) 'The Socio-Spatial Dialectic', Annals of the Association of American Geographers, 70(2), pp. 207-25.

Tawa Lama-Rewal, Stéphanie (2007) 'Neighborhood Associations and Local Democracy: Delhi Municipal Elections 2007', Economic and Political Weekly, 42(47), pp. 51-60.

Véron, René (2006) 'Remaking Urban Environments: The Political Ecology of Air Pollution in Delhi', Environment and Planning A, 38(11), pp. 2093-109.

Ward, Kevin; Imbroscio, David (2011) ‘Urban Politics: An Interdisciplinary Dialogue’, International Journal of Urban and Regional Research, 35(4), pp. 853-71.

Weiner, Myron; Osgoofield, John (1976) 'India's Urban Constituencies', Comparative Politics, 8(2), pp. 183-222.

Weinstein, Liza (2009) 'Democracy in the Globalizing Indian City: Engagements of Political Society and the State in Globalizing Mumbai', Politics \& Society, September, 37(3), pp. 397-427.

Whitehead, Judy; More, Nitin (2007) 'Revanchism in Mumbai? Political Economy of Rent Gaps and Urban Restructuring in a Global City’, Economic and Political Weekly, 42(25), pp. 2428-34.

Zérah, Marie-Hélène (2007) 'Middle Class Neighborhood Associations as Political Players in Mumbai', Economic and Political Weekly, 42(47), pp. 61-68.

Zérah, Marie-Hélène (2007) 'Conflict between Green Space Preservation and Housing Needs: The Case of the Sanjay Gandhi National Park in Mumbai', Cities, 24(2), pp. 122-32.

Zérah, Marie-Hélène (2009) 'Participatory Governance in Urban Management and the Shifting Geometry of Power in Mumbai', Development and Change, 40, pp. 853-77.

Zérah, Marie-Hélène (2011) 'Mumbai ou les enjeux de construction d'un acteur collectif', in Dominique Lorrain (ed.), Métropoles XXL en pays émergents, Paris: Presses de Sciences Po, pp. 139-214.

Zérah, Marie-Hélène; Dupont, Véronique; Tawa Lama-Rewal, Stéphanie (eds.) (2011) Urban Policies and the Right to the City in India: Rights, Responsibilities and Citizenship, UNESCO, Delhi: http:// unesdoc.unesco.org/images/0021/002146/214602E.pdf

\section{NOTES}

1. These are (by alphabetical order) Delhi (16.3 million), Dhaka (14.65 million), Karachi (13.12 million), Kolkata (14.1 million) and Greater Mumbai (18.4 million). Figures for Indian cities have recently been released by the Census of India for 2011 (http://www.censusindia.gov.in/2011prov-results/paper2/data_files/india2/Million_Plus_UAs_Cities_2011.pdf). Figures for Dhaka and Karachi are provided by the UN World Urbanization Prospects data for the year 2010 (see http:// esa.un.org/unpd/wup/index.htm).

2. We owe this expression to Alain Dubresson.

3. We owe this formulation, with gratitude, to Anant Mariganti.

4. These struggles often take place in specific places in the city and a comparative study of the spaces of urban protests would be welcome. Indeed, recent restrictions imposed on the use of Azad Maidan for protests (in Mumbai), as well as the project to beautify it (and consequently reduce the amount of open space), or the forbidden use of Sansad Marg in Delhi for large demonstrations point towards a trend of shrinking protest spaces. 
5. Author's italics.

6. The growing interest in urban studies is manifest in the increasingly large volume of publications on the urban-see for instance the new 'Review of urban affairs' of Economic and Political Weekly, or the much active, online 'urban study group' (http://www.sarai.net/mailinglists/urban-study). The city has captured the imagination not only of social scientists, but of the larger public: the success of books like 'Maximum City' by Suketu Mehta, of films like 'Slum dog millionaire' by Danny Boyle suggests a fascination with megacities and their collections of extremes-be it population, poverty, opulence or power...

7. For instance, see Haider \& Badami 2010.

8. The JNNURM was launched by the Indian Ministry of Urban Development in December 2005 for an initial period of seven years to encourage reforms in urban infrastructure. The programme targets a limited number of cities and provides for a considerable amount of funding. It imposes mandatory reforms and highlights the importance of governance issues through the application of the $74^{\text {th }}$ Constitutional Amendment Act, the enactment of a community participation law and a public disclosure law, all part of mandatory reforms.

9. The importance of this literature concerning Karachi and Mumbai suggests that comparison between these two cities could be very fruitful. Interestingly, most of the abstracts answering our Call for papers on 'Urban democracy in South Asia' focused on these two cities, reflecting the importance of party politics in their functioning.

10. Drawing on Bourdieu's notion of 'field', she characterizes the 'political field' of Kolkata as 'hegemonic' and that of Mumbai as 'fragmented'.

11. See for instance the constant work of the Urban Resource Centre in Karachi on housing rights and evictions.

12. See critiques of the Alliance's work in Sharma and Bhide 2005 and Zérah 2009.

13. This appropriation is made possible by the fact that the state has become more sensitive to the voice and interests of middle classes, but also to the interests of the private sector, and in particular the real estate lobby (as shown by Weinstein 2009), which further exacerbates processes of gentrification and marginalization of the urban poor.

14. Many works focusing on the actors of urban governance in today's India highlight the new importance of neighborhood associations (Tawa Lama-Rewal 2007, Zérah 2007, Chakrabarty 2008, Coelho \& Venkat 2009, Ghertner 2008, 2011). The now well-studied 'resident welfare associations' have benefited from the expansion of 'invited' spaces of participation (Miraftab 2004) focusing on local affairs. Participation is indeed a key word of the 'good governance' discourse that is much favoured today. New schemes have been launched by state or municipal governments in the 2000s, aiming at involving the middle class in the management of urban affairs, and more precisely in the improvement of service delivery (Tawa Lama-Rewal 2007, Zérah 2007, Baud and Nainan 2008, Paul 2006). Research has highlighted that the opening up of participatory spaces and the rising role of NGOs have spurred an assertive activism by the middle classes, and for the middle classes (Fernandes 2007, Ghertner 2008), an activism that resorts to press campaigns and judicial action (Dembovski 1999, Mawdsley 2004, Véron 2006, Dupont \& Ramanathan 2009).

15. The Right to Information Act (RTI) was passed in 2005 at the national level in India. The RTI makes it mandatory for officials, at all levels of government, to provide any document requested by a citizen (with a few exceptions) within 30 days of the application, or face sanctions (see http://righttoinformation.gov.in/). It is a powerful instrument of democratic control, and has indeed been used by various citizen groups to expose corruption and other types of wrongdoing by public authorities.

16. Another striking research gap in the literature on urban democracy in South Asia-one that is not addressed by this issue-concerns the role of various types of media in urban mobilizations. 
INDEX

Keywords: local democracy, urban governance, urban studies, cities, citizenship, Mumbai, Kolkata, Karachi, Ahmedabad

\section{AUTHORS}

\section{STÉPHANIE TAWA LAMA-REWAL}

Research Fellow, Centre National de la Recherche Scientifique, Paris

\section{MARIE-HÉLĖNE ZÉRAH}

Research Fellow, Institut de Recherche pour le Développement and Centre de sciences Humaines, New Delhi 